\title{
Long-term analysis of clear-sky new particle formation events and nonevents in Hyytiälä
}

\author{
Lubna Dada $^{1}$, Pauli Paasonen ${ }^{1}$, Tuomo Nieminen ${ }^{1,2}$, Stephany Buenrostro Mazon ${ }^{1}$, Jenni Kontkanen ${ }^{1}$, \\ Otso Peräkylä ${ }^{1}$, Katrianne Lehtipalo ${ }^{1,4}$, Tareq Hussein ${ }^{1,5}$, Tuukka Petäjä ${ }^{1}$, Veli-Matti Kerminen ${ }^{1}$, Jaana Bäck ${ }^{3}$, and \\ Markku Kulmala ${ }^{1}$
}

${ }^{1}$ Department of Physics, University of Helsinki, P.O. Box 64, 00014 Helsinki, Finland

${ }^{2}$ Department of Applied Physics, University of Eastern Finland, P.O. Box 1627, 70211 Kuopio, Finland

${ }^{3}$ Department of Forest Sciences, University of Helsinki, P.O. Box 27, 00014 Helsinki, Finland

${ }^{4}$ Laboratory of Atmospheric Chemistry, Paul Scherrer Institute (PSI), 5232 Villigen PSI, Switzerland

${ }^{5}$ Department of Physics, the University of Jordan, Amman 11942, Jordan

Correspondence to: Lubna Dada (lubna.dada@helsinki.fi)

Received: 26 September 2016 - Discussion started: 19 October 2016

Revised: 23 March 2017 - Accepted: 25 April 2017 - Published: 22 May 2017

\begin{abstract}
New particle formation (NPF) events have been observed all around the world and are known to be a major source of atmospheric aerosol particles. Here we combine 20 years of observations in a boreal forest at the SMEAR II station (Station for Measuring Ecosystem-Atmosphere Relations) in Hyytiälä, Finland, by building on previously accumulated knowledge and by focusing on clear-sky (noncloudy) conditions. We first investigated the effect of cloudiness on NPF and then compared the NPF event and nonevent days during clear-sky conditions. In this comparison we considered, for example, the effects of calculated particle formation rates, condensation sink, trace gas concentrations and various meteorological quantities in discriminating NPF events from nonevents. The formation rate of $1.5 \mathrm{~nm}$ particles was calculated by using proxies for gaseous sulfuric acid and oxidized products of low volatile organic compounds, together with an empirical nucleation rate coefficient. As expected, our results indicate an increase in the frequency of NPF events under clear-sky conditions in comparison to cloudy ones. Also, focusing on clear-sky conditions enabled us to find a clear separation of many variables related to NPF. For instance, oxidized organic vapors showed a higher concentration during the clear-sky NPF event days, whereas the condensation sink (CS) and some trace gases had higher concentrations during the nonevent days. The calculated formation rate of $3 \mathrm{~nm}$ particles showed a notable difference between the NPF event and nonevent days dur-
\end{abstract}

ing clear-sky conditions, especially in winter and spring. For springtime, we are able to find a threshold equation for the combined values of ambient temperature and CS, $\left(\mathrm{CS}\left(\mathrm{s}^{-1}\right)\right.$ $>-3.091 \times 10^{-5} \times T$ (in Kelvin) +0.0120 ), above which practically no clear-sky NPF event could be observed. Finally, we present a probability distribution for the frequency of NPF events at a specific CS and temperature.

\section{Introduction}

The effects of atmospheric aerosol particles on the climate system, human health and environmental interactions have raised interest in various phenomena associated with the formation, growth and loss of these particles (Pöschl, 2005; Seinfeld and Pandis, 2012; Apte et al., 2015). While primary emissions are a very important source of atmospheric aerosol particles, especially in terms of the aerosol mass loading, the particle number concentration is greatly affected by atmospheric new particle formation (NPF). During the last couple of decades, NPF has been observed to take place almost all over the world (Kulmala et al., 2004a; Zhang et al., 2011; Bianchi et al., 2016; Kontkanen et al., 2016a, 2017). Atmospheric NPF is thought to be the dominant source of the total particle number concentration (Kulmala et al., 2016) and a major source of cloud condensation nuclei in the global tro- 
posphere (Merikanto et al., 2009; Yu et al., 2010; Kerminen et al., 2012; Salma et al., 2016).

Understanding the NPF phenomenon requires understanding its precursors and pathways involved under different atmospheric conditions. For instance, high concentrations of low-volatility vapors result in a higher probability for NPF (Nieminen et al., 2015), whereas a high relative humidity and condensation sink (CS) tend to suppress NPF (Hyvönen et al., 2005; Nieminen et al., 2014). Recent laboratory experiments have shown the importance of sulfuric acid and low-volatile oxidized organic vapors to NPF (Metzger et al., 2010; Kirkby et al., 2011; Petäjä et al., 2011; Kulmala et al., 2013; Ehn et al., 2014; Riccobono et al., 2014). Additionally, atmospheric observations confirm the importance of these precursor vapors in the initial steps of NPF and in the further growth of newly formed particles (Kulmala et al., 1998; Smith et al., 2005; Kerminen et al., 2010; Paasonen et al., 2010; Ahlm et al., 2012; Bzdek et al., 2014; Nieminen et al., 2014; Vakkari et al., 2015). The Station for Measuring Forest Ecosystem-Atmosphere Relations (SMEAR II), located in Hyytiälä, southern Finland, compiles almost 21 years of particle number size distribution and extensive complementary data, providing the longest size distribution time series in the world, and hence allows for robust NPF analysis which is not readily possible at other sites. The station is located in a homogenous Scots pine forest far from major pollution sources. Hyytiälä is therefore classified as a background site representative of the semi-clean Northern Hemisphere boreal forests.

Many studies have investigated the role of different variables in causing, enhancing or preventing new particle formation (Hyvönen et al., 2005; Baranizadeh et al., 2014; Nieminen et al., 2014). In particular, Baranizadeh et al. (2014) studied the effect of cloudiness on NPF events observed at SMEAR II in Hyytiälä. They concluded, in agreement with some other studies, that clouds tend to attenuate or interrupt NPF events (Sogacheva et al., 2008; Boulon et al., 2010; Baranizadeh et al., 2014; Nieminen et al., 2015). In this study, we eliminated one variable that limits NPF (cloudiness) in order to provide a better insight into the other quantities related to atmospheric NPF. Based on 20 years of observations and data analysis for the SMEAR II station in Hyytiälä, we aim to (i) quantify the effect of cloudiness on new particle formation frequency, (ii) characterize the differences between NPF event and nonevent days during clear-sky conditions, (iii) explore the connections between new particle formation rates calculated from precursor vapor proxies and the occurrence of NPF events, (iv) formulate an equation that predicts whether a clear-sky day with specific temperature and CS is classified as an event, (v) use the clear-sky data set to calculate the NPF probability distribution based on temperature and CS.

\section{Materials and methods}

\subsection{Measurements}

The data used for the analysis in this study are from the University of Helsinki SMEAR II station (Hari and Kulmala, 2005). The station provides long-term continuous comprehensive measurements of quantities describing atmosphericforest-ecosystem interactions. The SMEAR II station is located in the boreal forest in Hyytiälä, southern Finland $\left(61^{\circ} 51^{\prime} \mathrm{N}, 24^{\circ} 17^{\prime} \mathrm{E}, 181 \mathrm{~m}\right.$ a.s.l.), $220 \mathrm{~km} \mathrm{NW}$ of Helsinki. Tampere (200000 inhabitants) is the largest city nearest to the station and is located $60 \mathrm{~km} \mathrm{SW}$ of the site. Being far from major human activities and surrounded by a homogenous Scots pine belt, Hyytiälä is considered a rural background site due to the low levels of air pollutants (Asmi et al., 2011). A more detailed overview of the measurements at the station can be found in Hari and Kulmala (2005) and Nieminen et al. (2014).

In this study, the data analysis is based on four types of measurements: (i) aerosol particle number size distributions, (ii) concentration of the trace gases $\left(\mathrm{CO}, \mathrm{NO}, \mathrm{NO}_{2}, \mathrm{NO}_{x}\right.$, $\mathrm{SO}_{2}$ and $\mathrm{O}_{3}$ ), (iii) meteorological parameters (solar radiation, temperature and relative humidity) and (iv) precursor vapor concentrations from previously developed proxies. The collection of data started in January 1996. Trace gas concentrations are measured at six different heights on a $74 \mathrm{~m}$-high mast (extended to $126 \mathrm{~m}$ in summer 2010). Gas concentrations used in this study are collected from the middle level on the mast above the forest (at $16.8 \mathrm{~m}$ ).

The aerosol number size distributions were measured with a twin DMPS (Differential Mobility Particle Sizer) system (Aalto et al., 2001) for the size ranges 3-500 nm until year 2004 and 3-1000 nm from 2005 onwards. These data were used to classify days as NPF events and nonevents following the method proposed by Dal Maso et al. (2005). The size distributions obtained from the DMPS measurements were used to calculate the CS, which is equal to the rate at which nonvolatile vapors condense onto a pre-existing aerosol particle population (Kulmala et al., 2012).

The CO concentration is measured with one infrared light absorption analyzer (API 300EU, Teledyne Monitor Labs, Englewood, CO, USA). The $\mathrm{NO}$ and $\mathrm{NO}_{x}$ concentrations are monitored with a chemiluminescence analyzer (TEI 42C TL, Thermo Fisher Scientific, Waltham, MA, USA). The $\mathrm{NO}_{2}$ concentration is calculated from the difference $\mathrm{NO}_{x}-\mathrm{NO}$. The detection limit is about $0.05 \mathrm{ppb} . \mathrm{SO}_{2}$ measurements are made through a UV fluorescence analyzer (TEI 43 CTL, Thermo Fisher Scientific, Waltham, MA, USA) that has a detection limit of $0.1 \mathrm{ppb}$. The $\mathrm{O}_{3}$ concentration is measured with an UV light absorption analyzer (TEI 49C, Thermo Fisher Scientific, Waltham, MA, USA) that has a detection limit of about $1 \mathrm{ppb}$. The data for trace gases are available as 30 min arithmetic means. 
Solar radiation in the wavelengths of UV-B $(280-320 \mathrm{~nm})$ and global radiation $(0.30-4.8 \mu \mathrm{m})$ are monitored using pyranometers (SL 501A UVB, Solar Light, Philadelphia, PA, USA; Reeman TP 3, Astrodata, Tõravere, Tartumaa, Estonia until June 2008, and Middleton Solar SK08, Middleton Solar, Yarraville, Australia since June 2008) above the forest at $18 \mathrm{~m}$. The air temperature is measured with 4-wire PT-100 sensors, and the relative humidity (in percent) is measured with relative humidity sensors (Rotronic Hygromet MP102H with Hygroclip HC2-S3, Rotronic AG, Bassersdorf, Switzerland). These data are provided as $30 \mathrm{~min}$ averages.

\subsection{Data analysis}

\subsubsection{New particle formation events classification}

The formation of new aerosol particles in Hyytiälä is typically observed in the time window of several hours around noon, while this phenomenon seems to be rare during nighttime (Junninen et al., 2008; Buenrostro Mazon et al., 2016). Accordingly, aerosol number size distribution data from the DMPS measurements at around this time window are used for classifying individual days as new particle formation event or nonevent days. The classification follows the guidelines presented by Kulmala et al. (2012) and the procedure presented in Dal Maso et al. (2005). The latter uses a decision criterion based on the presence of particles $<25 \mathrm{~nm}$ in diameter and their consequent growth to Aitken mode. Event days are days on which sub- $25 \mathrm{~nm}$ particle formation and growth are observed. Nonevent days are days on which neither modes are present. Undefined days are the days which do not fit either criterion.

\subsubsection{Selecting noncloudy days}

The cloudiness parameter $(P)$ is the ratio of measured global radiation $(\mathrm{Rd})$ divided by the theoretical global irradiance $(\mathrm{Rg})$ :

$P=\frac{\mathrm{Rd}}{\mathrm{Rg}}$.

The theoretical maximum of global radiation $(\mathrm{Rg})$ is calculated by taking into consideration the latitude of the measurement station and the seasonal solar cycle. While a complete cloud coverage is classified as $P<0.3$, a clear-sky is classified as $P>0.7$ (Perez et al., 1990; Sogacheva et al., 2008; Sánchez et al., 2012). In Hyytiälä, the great majority of NPF events are initiated during the morning hours after sunrise, but before noon (Dada et al., 2017). Since the time of sunrise varies widely in Hyytiälä between the different seasons, the time window 09:00-12:00 seems a reasonable compromise for considering whether NPF occurred or not. We found that NPF events occurring outside our selected time window were very few. Accordingly, in this work, the days were classified as cloudy or clear-sky days based on the median value of $P$ during 09:00-12:00 each day, corresponding to the time window for new particle formation. The median value ensures that at least half of our selected time window is clear-sky while the rest can vary between clear-sky and minor scattered clouds. The median is also useful because NPF is a regional-scale phenomenon, so for instance, scattered clouds on an otherwise sunny day affecting the local radiation measurements (and leading to a momentarily drop in $P$ ) do not usually interrupt the regional NPF process. Clearsky days were those with a median of $P>0.7$ between 09:00 and 12:00 and are the focus of this study. For consistency, the variables compared in our study are taken from the same time window, 09:00-12:00.

\subsubsection{Sulfuric acid and oxidized organics proxies}

The gaseous sulfuric acid concentration is estimated from a pseudo-steady-state-approximation proxy developed by Petäjä et al. (2009). This proxy takes into consideration the sulfuric acid source and sink terms as

$\left[\mathrm{H}_{2} \mathrm{SO}_{4}\right]_{\text {proxy }}=k \cdot \frac{\left[\mathrm{SO}_{2}\right] \cdot \mathrm{UVB}}{\mathrm{CS}}$.

Here, UVB $\left(\mathrm{W} \mathrm{m}^{-2}\right)$ is the fraction of the UV radiation reaching the earth after being screened by ozone (280$320 \mathrm{~nm})$. The coefficient $k\left(\mathrm{~m}^{2} \mathrm{~W}^{-1} \mathrm{~s}^{-1}\right)$ is obtained from the comparison of the proxy concentration to the available measured $\mathrm{H}_{2} \mathrm{SO}_{4}$ data and has a median value of $9.9 \times 10^{-7} \mathrm{~m}^{2} \mathrm{~W}^{-1} \mathrm{~s}^{-1}$.

The concentration of monoterpene oxidation products, called oxidized organic compounds (OxOrg) here, is estimated using a proxy developed by Kontkanen et al. (2016b). This proxy is calculated by using the concentrations of different oxidants (the measured ozone concentration $\left[\mathrm{O}_{3}\right]$ and parameterizations for the hydroxyl and nitrate radical concentration, $[\mathrm{OH}]$ and $\left[\mathrm{NO}_{3}\right]$, respectively) and their reaction rates, $k_{i}$, with the monoterpenes. The $\mathrm{MT}$ proxy (in this case $\mathrm{MT}_{\text {proxy1,doy }}$ ) is calculated by taking into account the effect of temperature-driven emissions, the mixing of the boundary layer and the oxidation of monoterpenes (Kontkanen et al., 2016b).

[OxOrg $]_{\text {proxy }}$

$=\frac{\left(\mathrm{k}_{\mathrm{OH}+\mathrm{MT}}[\mathrm{OH}]+k_{\mathrm{O}_{3}+\mathrm{MT}}\left[\mathrm{O}_{3}\right]+k_{\mathrm{NO}_{3}+\mathrm{MT}}\left[\mathrm{NO}_{3}\right]\right) \cdot \mathrm{MT}_{\text {proxy }}}{\mathrm{CS}}$

\subsubsection{Particle formation rates}

The formation rate of nucleation mode particles $\left(J_{3, C}\right.$, particle diameter $>3 \mathrm{~nm}$ ) was calculated based on the method suggested by Kerminen and Kulmala's equation (Kerminen and Kulmala, 2002). This quantity is a function of the calculated formation rate of $1.5 \mathrm{~nm}$-sized particles $\left(J_{1.5, C}\right)$, their growth rate $(\mathrm{GR})$ and the $\mathrm{CS}$ :

$J_{3, C}=J_{1.5, C} \exp \left(-\gamma \frac{\mathrm{CS}^{\prime}}{\mathrm{GR}_{1.5-3}}\left(\frac{1}{1.5}-\frac{1}{3}\right)\right)$, 
(a)

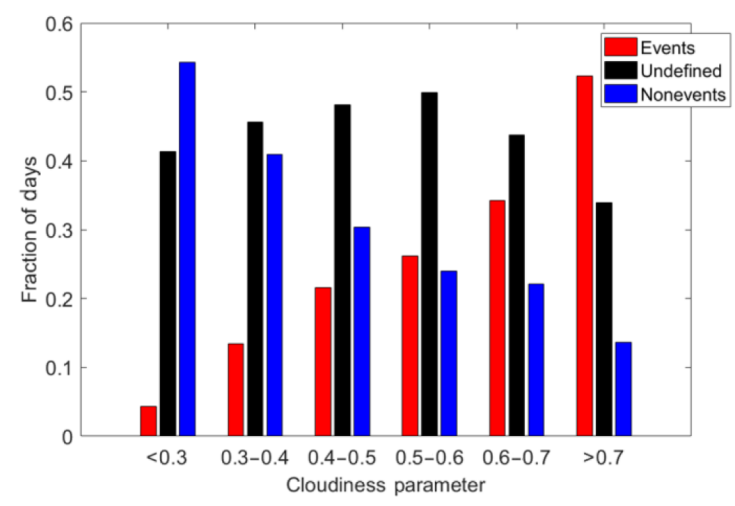

(b)

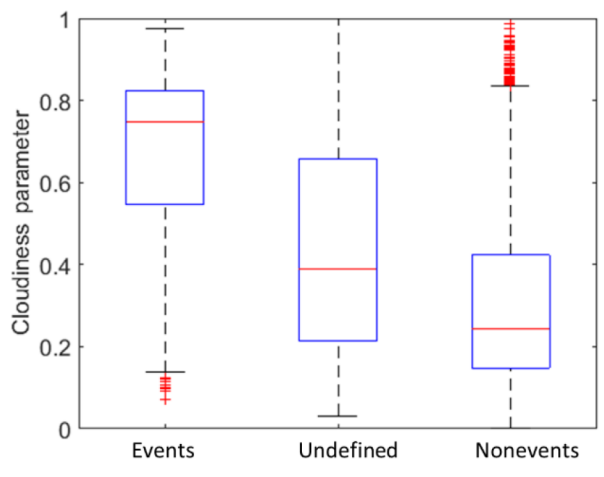

Figure 1. (a) Figure showing the fraction of days which are classified as NPF events, nonevents and undefined days during different sky cloudiness conditions. (b) Daily (09:00-12:00) medians and percentiles of cloudiness recorded during NPF event, undefined and nonevent days. The red line represents the median of the data and the lower and upper edges of the box represent 25 th and 75 th percentiles of the data, respectively. The length of the whiskers represent $1.5 \times$ interquartile range which includes $99.3 \%$ of the data. Data outside the whiskers are considered outliers and are marked with red crosses.

where $\gamma$ is a coefficient with an approximate value of $0.23 \mathrm{~m}^{3} \mathrm{~nm}^{2} \mathrm{~s}^{-1}$. The value of $J_{1.5, C}$ was calculated by assuming heteromolecular nucleation between SA and OxOrg as follows:

$$
J_{1.5, C}=K_{\text {het }}\left[\mathrm{H}_{2} \mathrm{SO}_{4}\right]_{\text {proxy }}[\mathrm{OxOrg}]_{\text {proxy }} .
$$

The heterogeneous nucleation coefficient used in Eq. (5) is the median estimated coefficient for Hyytiälä scaled from Paasonen et al. (2010): $K_{\text {het }}=9.2 \times 10^{-14} \mathrm{~cm}^{3} \mathrm{~s}^{-1}$. The scaling was made in order to fit the current data. The median value of [OxOrg] during the event days in April and May was found to be $1.6 \times 10^{7} \mathrm{~cm}^{-3}$ (Paasonen et al., 2010), whereas the revised median value of $[\mathrm{OxOrg}]$ by Kontkanen et al. (2016b) is $1.3 \times 10^{8} \mathrm{~cm}^{-3}$. The scaling factor is the ratio between new and original [OxOrg] (0.1194). Accordingly, while the value of $K_{\text {het }}$ from Paasonen et al. (2010) is $1.1 \times 10^{-14} \mathrm{~cm}^{3} \mathrm{~s}^{-1}$, after the scaling by 0.1194 we obtain the revised $K_{\text {het }}=9.2 \times 10^{-14} \mathrm{~cm}^{3} \mathrm{~s}^{-1}$.

The particle growth rate over the particle diameter range of 1.5-3 nm was calculated by taking into account the size of the condensing vapor molecule size and the thermal speed of the particle (Nieminen et al., 2010). The growth rates (1.5$3 \mathrm{~nm}$ ) were calculated as $30 \mathrm{~min}$ averages and as the sum of the growth rates due to the sulfuric acid (SA) vapor and OxOrg vapor condensation. The density of the particle was assumed to be constant $\left(1440 \mathrm{~kg} \mathrm{~m}^{-3}\right)$. For SA, we first determined the SA concentration needed to make the particles grow at the rate of $1 \mathrm{~nm} / \mathrm{h}$ by taking into account the mass of hydrated SA at the present RH and its density (Kurtén et al., 2007). Then, we calculated the GR of the particles due to SA condensation by using the SA proxy concentration. The same method was used for GR due to OxOrg condensation, where the vapor density was assumed to be $1200 \mathrm{~kg} \mathrm{~m}^{-3}$ (Hallquist et al., 2009; Kannosto et al., 2008). Similarly, the GR due to
OxOrg was calculated by using OxOrg proxy concentrations divided by the concentration needed for $1 \mathrm{~nm} \mathrm{~h}^{-1} \mathrm{GR}$.

\subsubsection{Calculation of backward air mass trajectories}

Air mass trajectories were calculated using the Hybrid Single-Particle Lagrangian Integrated Trajectory (HYSPLIT_4) model at 96 h backward trajectories at 100, 250 and $500 \mathrm{~m}$ arrival heights once per hour.

\section{Results and discussion}

\subsection{Effect of cloudiness on NPF}

We studied NPF events as a function of cloudiness. Figure 1a shows the fraction of event, nonevent and undefined days as a function of cloudiness parameter. We can see that clear-sky conditions favor the occurrence of NPF: the fewer clouds there were, the higher was the fraction of NPF event days. For instance, for days with the cloudiness parameter of 0.3 or less, the fraction of event days was less than 0.1 of the total classified days. However, the fraction of NPF event days reached a maximum of around 0.55 during complete clear-sky conditions $(P>0.7)$, with 877 days classified as NPF events, 560 undefined days and only 229 as nonevents. On the NPF event days, the median cloudiness parameter $P$ during the time window 09:00-12:00 was found to be 0.75 (Fig. 1b), while the nonevent days were characterized by lower values of $P$ (a median of around 0.25 ). Also, $75 \%$ of the NPF event days were found to have a cloudiness parameter larger than 0.5. The pattern found in Fig. 1a follows from the fact that radiation seems essential for NPF at this site, as the events occur almost solely during daylight hours (Kulmala et al., 2004b). Also, NPF is favored under abundant radiation conditions since the main components of 


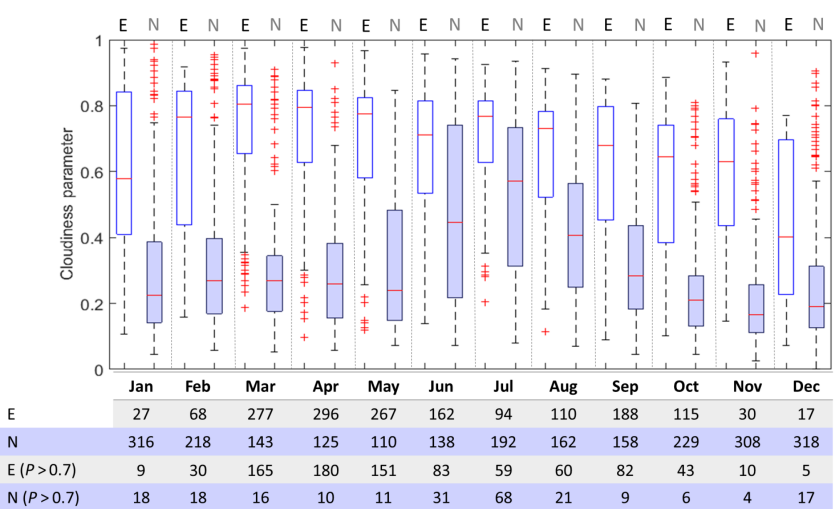

Figure 2. Monthly variation of cloudiness daily (09:00-12:00) medians and percentiles recorded during NPF events (E; white) and nonevents ( $\mathrm{N}$; shaded). Numbers below the plot correspond to the number of data points included in each box plot. Number of clearsky events $(\mathrm{E}(P>0.7))$ and clear-sky nonevents $(\mathrm{N}(P>0.7))$ accompany the plot. See Fig. 1 for an explanation of symbols.

freshly formed particles are mainly formed photochemically (Petäjä et al., 2009; Ehn et al., 2014). The fraction of undefined days, however, remained constant regardless of cloudiness conditions.

Our results emphasize the fact that radiation favors the occurrence of NPF, while clouds tend to decrease the probability of NPF. Undefined days were observed under cloudiness conditions that fell between those for NPF events and nonevents. In general, undefined days can be interrupted NPF events or unclassified plumes of small particles due to pollution (Buenrostro Mazon et al., 2009). The interruption of a NPF event can be due to a change in the measured air mass or to the attenuation of solar radiation caused by the appearance of a cloud during the event. We will not consider undefined days further in our analyses.

The monthly variation of daily median cloudiness parameter within the time window of 09:00-12:00 during the classified days is shown in Fig. 2. Spring showed the best separation between the events and nonevents in terms of the cloudiness parameter, while the separation became weaker during the summer and especially for June and July. Taken together, Figs. 1 and 2 emphasize the observation that the presence of clouds decreases the probability of NPF events.

\subsection{General character of NPF on clear-sky days}

Upon visualizing the cloudiness conditions during events and nonevents, we chose a fixed constraint for clear-sky conditions $(P>0.7)$ during the time window of NPF (09:0012:00) and will focus on other parameters that distinguish NPF events from nonevents in the following.

The monthly distribution of the event fraction on clearsky days appeared as double peaks in spring and autumn, with spring having a higher fraction of events (Fig. 3a). The minimum fraction of NPF events was recorded in December.
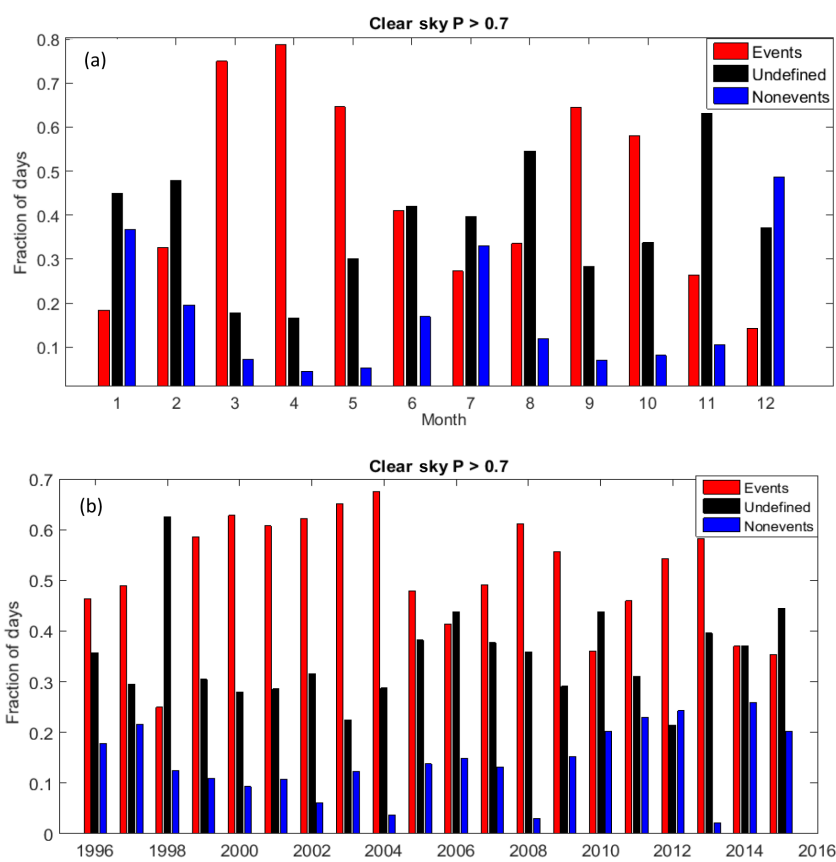

Figure 3. (a) Monthly and (b) yearly fraction of clear-sky days classified as NPF events, undefined and nonevents. In 1998, global radiation data are limited to $5.4 \%$, leading to the classification bias.

The fraction of nonevent days peaked in winter with another peak in summer. The total number of NPF events varied from year to year between 1996 and 2015. However, this variation did not show any specific trend of frequency (Fig. 3b), which is in agreement with previous statistics reported from studies that did not consider clear-sky classification (Nieminen et al., 2014).

\subsubsection{Backward air mass trajectories during clear-sky NPF events and nonevents}

Since NPF is most frequent in spring, we dedicated our focus to this season (Fig. 3a). The springtime medians and percentiles of air mass trajectories arriving at Hyytiälä during clear-sky NPF events and nonevents were calculated $96 \mathrm{~h}$ backward in time at the 100,250 and $500 \mathrm{~m}$ arrival heights for the years 1996-2015. The medians and similarly the percentiles were calculated by taking the median compass direction at every point on the trajectory ( $1 \mathrm{~h}$ between every two points), arriving every half an hour at Hyytiälä. The trajectories arriving at Hyytiälä at these three heights were quite similar, and those arriving at the $500 \mathrm{~m}$ height are shown in Fig. 4. Medians and percentiles of the routes were calculated by taking the median of the trajectories at every half hour for springtime NPF event days and nonevent days separately. During the NPF event days, the measured air masses were found to originate mainly from the north and passed over Scandinavia before arriving at Hyytiälä. Similarly to previously reported results, air masses arriving from the north and 
Table 1. Correlation coefficients between different meteorological parameters, gas concentrations and condensation sink (CS) during clear-sky events and nonevents during spring (March-May, 19962015) and time window 09:00-12:00. High positive and negative correlations are marked in bold.

\begin{tabular}{lrrrrrrr}
\hline & $\mathrm{CS}$ & $T$ & $\mathrm{RH}$ & $\mathrm{CO}$ & $\mathrm{NO}_{x}$ & $\mathrm{SO}_{2}$ & $\mathrm{O}_{3}$ \\
\hline \multicolumn{7}{c}{ Events } \\
\hline $\mathrm{CS}$ & 1 & & & & & & \\
$T$ & 0.28 & 1 & & & & & \\
$\mathrm{RH}$ & -0.06 & -0.64 & 1 & & & & \\
$\mathrm{CO}$ & 0.33 & -0.37 & 0.26 & 1 & & & \\
$\mathrm{NO}_{x}$ & 0.53 & -0.19 & 0.21 & 0.47 & 1 & 1 & \\
$\mathrm{SO}_{2}$ & 0.4 & -0.29 & 0.14 & 0.36 & 0.58 & 1 \\
$\mathrm{O}_{3}$ & 0.23 & 0.52 & -0.51 & -0.06 & -0.08 & -0.08 & 1 \\
\hline & & \multicolumn{7}{c}{ Nonevents } & & & \\
\hline $\mathrm{CS}$ & 1 & & & & & & \\
$T$ & 0.15 & 1 & & & & & \\
$\mathrm{RH}$ & -0.12 & $-\mathbf{0 . 8 1}$ & 1 & & & & \\
$\mathrm{CO}$ & 0.53 & $-\mathbf{0 . 6 8}$ & 0.5 & 1 & & & \\
$\mathrm{NO}_{x}$ & 0.34 & -0.51 & 0.45 & $\mathbf{0 . 7}$ & 1 & & \\
$\mathrm{SO}_{2}$ & 0.23 & -0.55 & 0.42 & 0.56 & 0.41 & 1 & \\
$\mathrm{O}_{3}$ & 0.43 & 0.62 & -0.64 & $-4 \mathrm{E}-04$ & -0.07 & -0.13 & 1 \\
\hline & & & & & & &
\end{tabular}

north-west directions result in clean air with low pollutant (particulate matter and trace gas) concentrations (Nieminen et al., 2015). During NPF the nonevent days, air masses originated from more polluted areas in Europe and Russia, resulting in elevated levels of condensation sink and other air pollutants in Hyytiälä, as also seen in previous studies (Sogacheva et al., 2005).

\subsection{Influences of CS, meteorological parameters and trace gases}

In Fig. 5a we present the monthly variation of condensation sink during NPF events and nonevents under daytime clearsky conditions. NPF events tended to be favored by low values of CS throughout the year. In all months except during summer, the 75th percentile of the event day values of CS was lower than the 25th percentile of the nonevent day values of CS. On the NPF event days, CS had its maximum in summer, which might be one of the main reasons for the local minimum in the NPF event frequency during the summer months (Fig. 3a). However, the monthly cycle of CS during nonevent days had two maxima, one in spring and another one in autumn, which might suggest that during these seasons, high values of CS prevented NPF occurring on particular days. The difference in the value of CS between the NPF event and nonevent days was the highest in March and the lowest during the summer months.

Figure $5 \mathrm{~b}$ shows the monthly temperature conditions $(T)$ during the daytime NPF events and nonevents. While higher temperatures favored NPF during months when the average temperature was below $273.15 \mathrm{~K}\left(0^{\circ} \mathrm{C}\right.$; months $1,2,3,11$ and 12), the opposite was true at average temperatures above $273.15 \mathrm{~K}\left(0^{\circ} \mathrm{C}\right)$. From our data set, clear-sky events occurred within temperatures ranging between $252 \mathrm{~K}\left(-21^{\circ} \mathrm{C}\right)$ and $300 \mathrm{~K}\left(25^{\circ} \mathrm{C}\right)$. Days with higher or lower temperatures than the range mentioned above are found to be nonevents. Accordingly, both very high and very low temperatures were not favorable conditions for NPF. Although an increase in the ambient temperature results in higher concentrations of monoterpenes due to increased emissions, thereby favoring new particle formation and growth (Kulmala et al., 2004a), Fig. 5b shows that very high temperatures tend to suppress NPF. This latter feature is at least partly related to the positive relation between the ambient temperature and pre-existing aerosol loading (and hence CS) in Hyytiälä (Liao et al., 2014), even though it might also be attributed to the increase in vapor evaporation coefficients, which results in less stable clusters at high temperatures (Paasonen et al., 2012).

As with an earlier study (Hamed et al., 2011), our results indicate that NPF is favored by low values of ambient relative humidity in Hyytiälä (Fig. 5c). This observation does not conflict with chamber experiments (e.g., Duplissy et al., 2016) or theory (Merikanto et al., 2016; Vehkamäki et al., 2002), which suggest higher nucleation rates at higher values of $\mathrm{RH}$, because binary $\mathrm{H}_{2} \mathrm{SO}_{4}$-water nucleation is not expected take place in Hyytiälä. Other studies have proposed that increased RH limits some VOC (Volatile Organic Compounds) ozonolysis reactions, preventing the formation of come condensable vapors necessary for nucleation (Boy and Kulmala, 2002). This might partially explain the observed anti-correlation between $\mathrm{RH}$ and particle formation rates. Therefore, it seems plausible that RH affects NPF via atmospheric chemistry rather than by changing the sink term for condensing vapors and small clusters. Additionally, we found clear differences in how trace gas concentrations were associated with RH between the NPF event and nonevent days (Table 1). For instance, $\mathrm{O}_{3}$ showed a strong negative correlation with RH during events and nonevents. However, during nonevent days, a positive correlation appears between $\mathrm{RH}$ and each of $\mathrm{CO}, \mathrm{SO}_{2}$ and $\mathrm{NO}_{x}$ while the correlation between them seems to be absent during event days. Our results show that air masses coming from central Europe and passing over the Baltic Sea tend to have higher values of RH.

After looking at the characteristics of clear-sky NPF event and nonevent days in terms of meteorological parameters and $\mathrm{CS}$, we looked at the variation of trace gas $\left(\mathrm{CO}, \mathrm{SO}_{2}\right.$, $\mathrm{NO}_{x}$ and $\mathrm{O}_{3}$ ) concentrations during these conditions (Fig. 6). Out of these gases, at least $\mathrm{SO}_{2}$ and $\mathrm{O}_{3}$ are expected to enhance NPF, $\mathrm{SO}_{2}$ as a precursor for sulfuric acid and $\mathrm{O}_{3}$ as an oxidant forming ELVOCs (extremely low volatile organic compounds; Donahue et al., 2012; Ehn et al., 2014). However, none of these vapors seemed to have higher concentrations during NPF event days. This suggests that, as tracers of pollution, these gases are strongly linked with high anthropogenic CS, so air masses with high trace gas concentrations often do not result in NPF in Hyytiälä. 


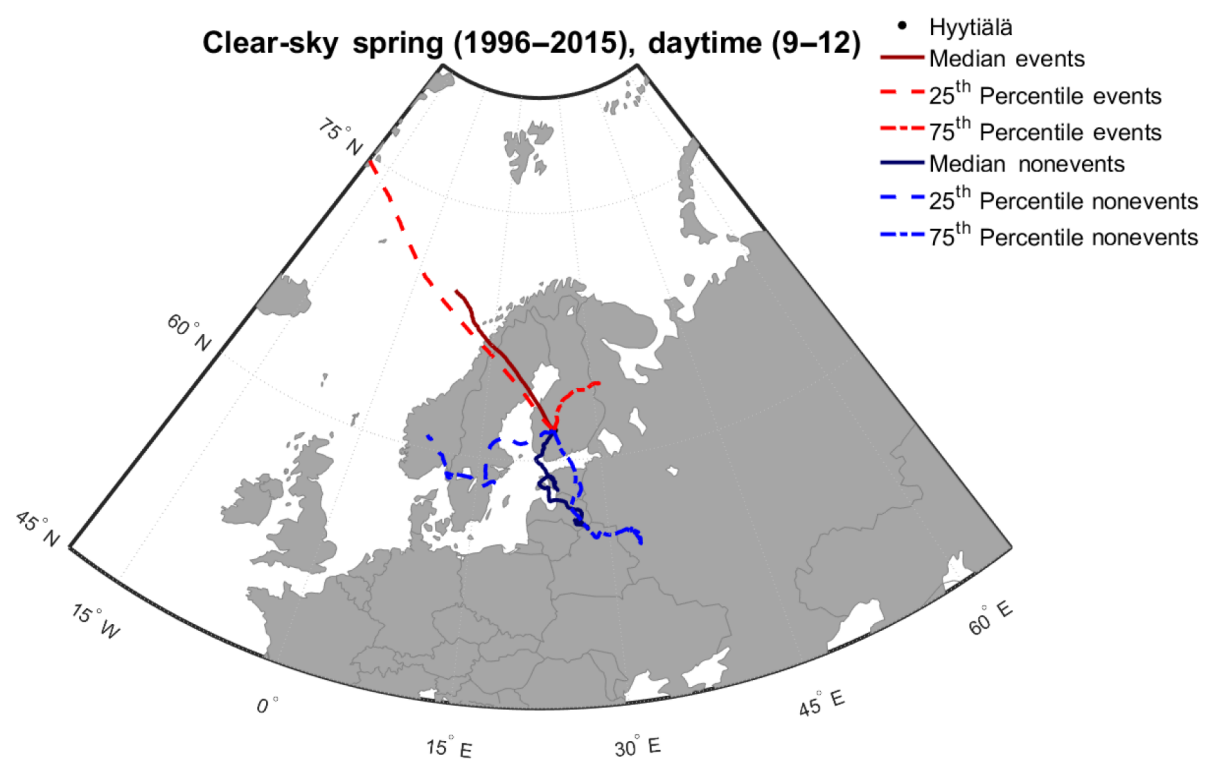

Figure 4. Median and percentiles of $96 \mathrm{~h}$ backward air mass trajectories arriving at Hyytiälä during springtime (09:00-12:00).

\subsection{Connection of nucleating precursor vapors with new particle formation rate}

\subsubsection{Precursor vapor proxies}

In this study, we determined $J_{1.5, C}$ using the proxies for both SA and OxOrg. The monthly variations of these precursors (in the time window 09:00-12:00) are shown in Fig. 7. During clear-sky conditions, the SA proxy tended to have the highest median daytime values during the winter months with a maximum in February (Fig. 7a). Contrary to this, the seasonal distribution of the SA proxy reported in Hyytiälä appears as double peaks with an absolute maximum in spring and a smaller one in autumn when presenting the data, without excluding cloudy days (Nieminen et al., 2014). During winter, both condensation sink and boundary layer height are lower than in the summer (Paasonen et al., 2013), which might explain the higher concentrations of SA during the winter months.

Being a function of temperature, the OxOrg proxy concentration was generally found to follow the monthly cycle of the ambient temperature. The median value of [OxOrg] was higher on NPF events days in every month compared with nonevent days (Fig. 7b). The largest difference in [OxOrg] between the NPF events and nonevents, in terms of its median value, was recorded for January and the least difference was recorded for May. It is to be noted that the proxy values represent the measured values less accurately during winter than during the other periods (Kontkanen et al., 2016b).

\subsubsection{Particle formation rates}

The calculated new particle formation rate, $J_{1.5, C}$, approximated with Eq. (5) shows a similar behavior to the [Ox-
Org] (see Figs. 7 and 8), being higher for the clear-sky NPF event days in comparison with nonevent days. Also, the difference in the value of $J_{1.5, C}$ between the NPF events and nonevents was highest in the winter and lowest in summer. The monthly cycle of $J_{1.5, C}$ closely followed that of [OxOrg], as the latter had a higher seasonal variability than the sulfuric acid proxy concentration, thereby being capable of affecting the seasonal pattern of $J_{1.5, C}$ (Fig. 8a). The diurnal cycle of $J_{1.5, C}$ during the NPF event days showed an increase along with sunrise, a peak at midday and decrease along with sunset. However, for nonevent days the $J_{1.5, C}$ value was relatively constant throughout the day and had clearly lower values than during the NPF event days (Fig. 8b).

Since previous studies have shown that there is a clear difference in observed $J_{3}$ between the event and nonevent days and much less difference in observed $J_{1.5}$ (Kulmala et al., 2013), we decided to focus on $J_{3}$ in our event to nonevent discrimination. Previous studies which did not consider clearsky conditions have reported values of observed springtime $J_{3}$ between 0.01 and $5 \mathrm{~cm}^{-3} \mathrm{~s}^{-1}$ (median $=0.94 \mathrm{~cm}^{-3} \mathrm{~s}^{-1}$ ) during the period of active NPF (Kulmala et al., 2013). Our values of $J_{3, C}$ fit between the extremes of these values for the springtime and time window 09:00 to 12:00, with a slightly higher median value of $1.9 \mathrm{~cm}^{-3} \mathrm{~s}^{-1}$ (Figs. 9a, b). The formation rate of $3 \mathrm{~nm}$ particles is not only affected by the new particle formation rate $\left(J_{1.5}\right)$ but also by the scavenging of newly formed particles by coagulation into pre-existing particles. We found that, in general, the values of $J_{3, C}$ calculated using Eqs. (4) and (5) were higher on NPF event days compared with nonevent days in all months (Fig. 9a). The difference between the event and nonevent days was the largest in winter and decreased towards summer. However, the diurnal cycles of percentiles and medians of $J_{3, C}$ during each month 

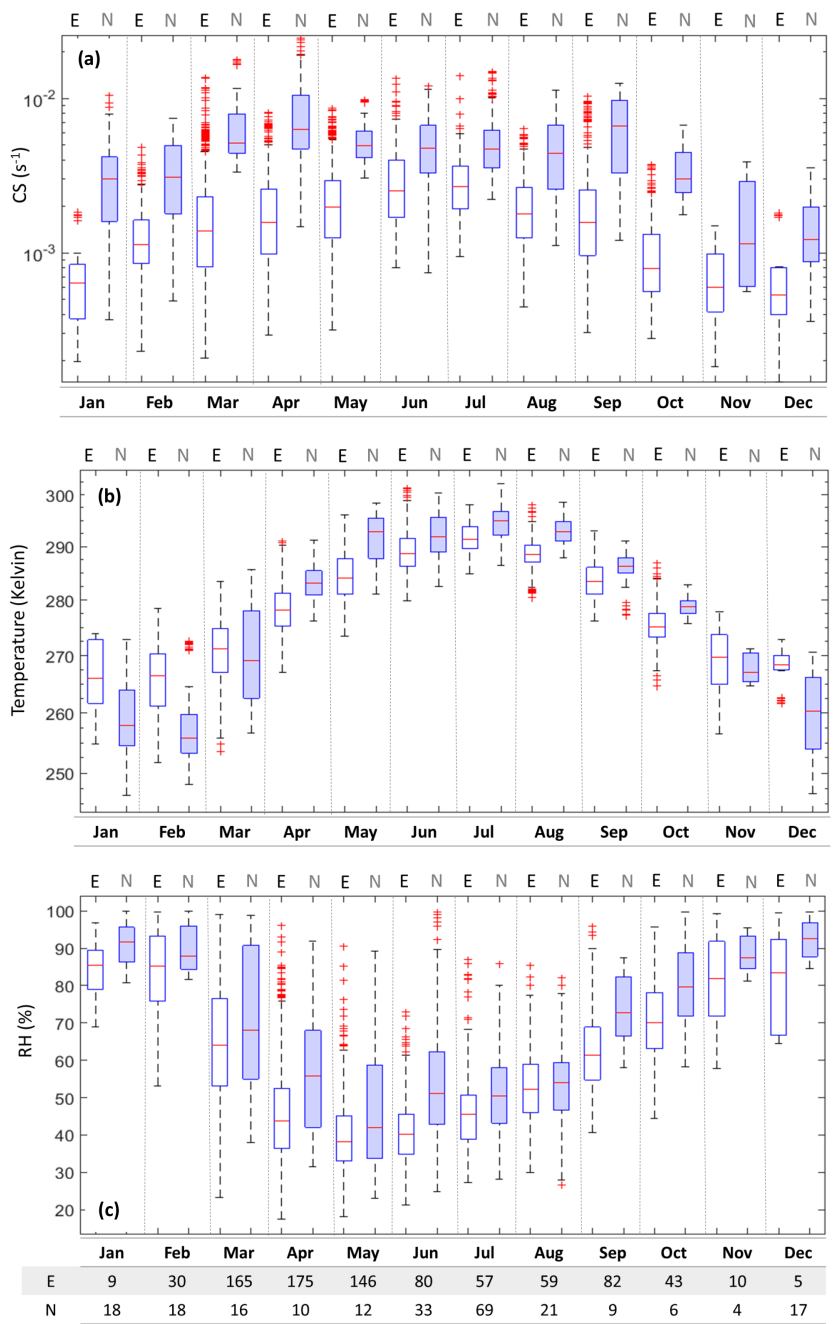

Figure 5. Median and percentiles of monthly variation (09:0012:00) at $P>0.7$ of (a) CS, (b) temperature and (c) RH during NPF events (E, white) and nonevents (N, shaded). See Fig. 1 for explanation of symbols.

peaked around noon for both NPF events and nonevents. One example is presented in Fig. 9b, showing that $J_{3, C}$ tended to increase after sunrise, peak at about midday and diminish after sunset. This kind of diurnal cycle was similar for all months. Hourly values of $J_{3, C}$ calculated during the NPF event days were higher than those during the nonevent days. During the spring months, the difference in the median $J_{3, C}$ between the NPF events and nonevents, calculated for every half an hour, appeared to increase at about 10:00 and then started to decrease again at about 13:00 (Fig. 9b). On NPF event days, in comparison to springtime $J_{1.5, C}$ which peaked at around 10:45 (Fig. 8b), $J_{3, C}$ peaked typically about half an hour later. This time delay indicates how long it takes for the particles to grow from 1.5 to $3 \mathrm{~nm}$. This growth is a critical step of NPF (Kulmala et al., 2013) and it depends on concentrations of available vapor precursors.

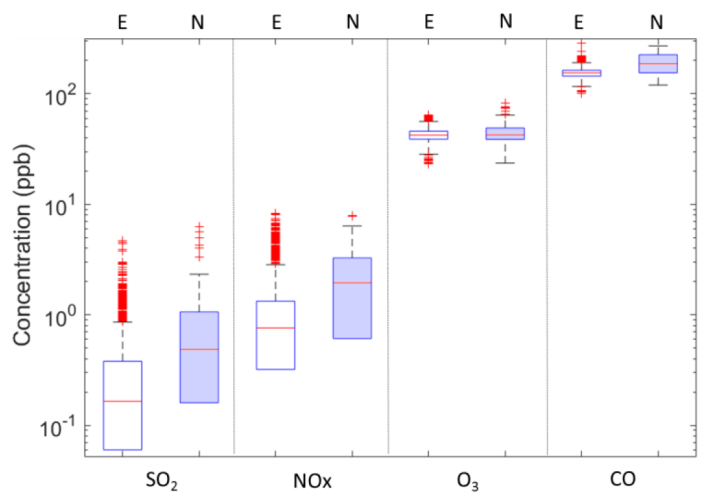

Figure 6. Springtime (months 3, 4, 5) medians and percentiles of trace gases during clear-sky events $(\mathrm{E}$, white) and nonevents (n, shaded) during daytime (09:00-12:00). See Fig. 1 for explanation of symbols.
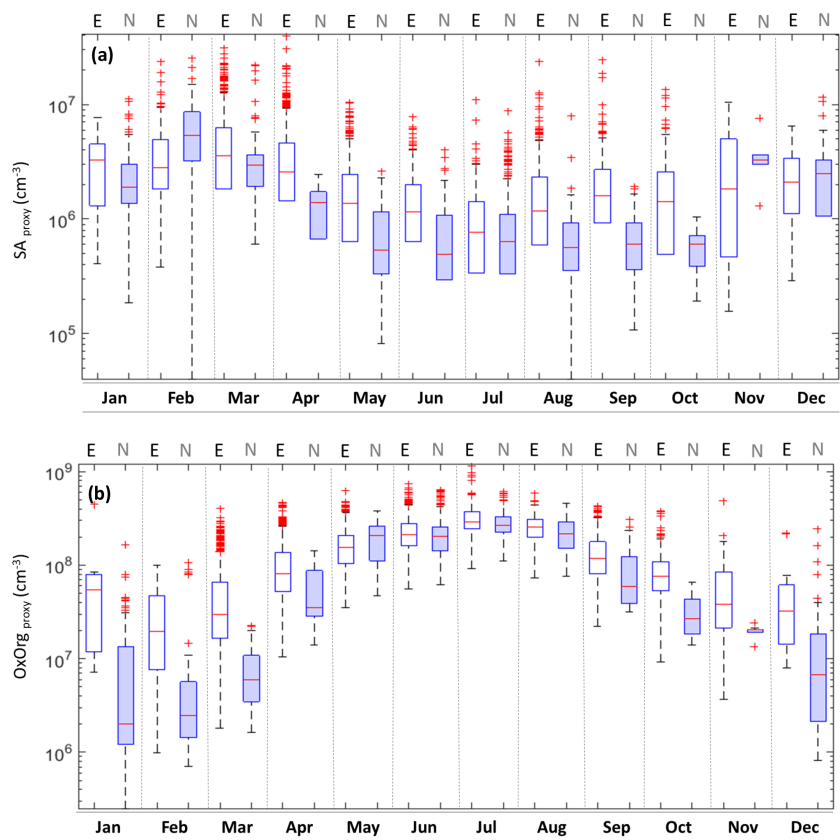

Figure 7. Monthly variation of medians and percentiles of (a) SA proxy and (b) OxOrg proxy at $P>0.7$ during the time window 09:00-12:00 of NPF events (E, white) and nonevents (N, shaded). See Fig. 1 for explanation of symbols.

In Fig. 10 we present the median diurnal cycles of $J_{3, C}$ and CS during classified clear-sky NPF events and nonevents. The diurnal cycle was calculated by taking the median CS at every half hour throughout the season. On the NPF event days, the CS had higher values during the nighttime and lower values during daytime with a minimum at noon. It is important to remember that $J$ was calculated only for daytime when the SA proxy was available (UV-B radiation is needed for the proxy). On nonevent days, the values of CS showed no clear diurnal pattern, had practically 

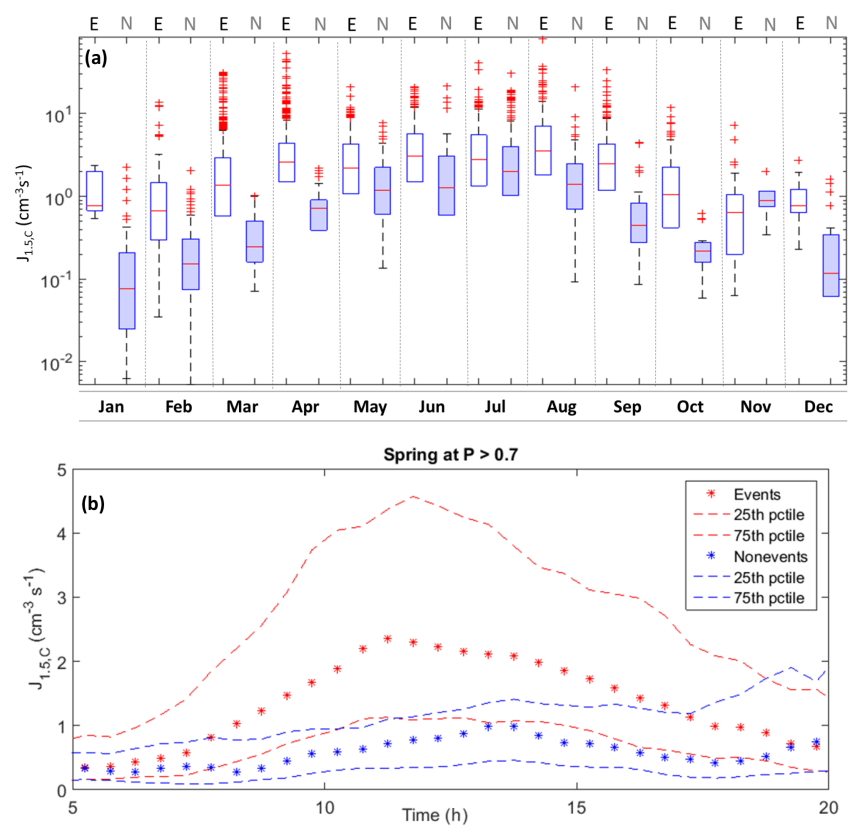

Figure 8. (a) Monthly variation of medians and percentiles of $J_{1.5, C}$ during the time window 09:00-12:00 of NPF events (E, white) and nonevents (N, shaded). See Fig. 1 for explanation of symbols. (b) The diurnal cycle of $J_{1.5, C}$ during spring. Nighttime is missing in this plot due to unavailable SA proxy which uses UVB to be calculated.

no difference between the daytime and nighttime hours and were roughly twice those recorded during the clear-sky NPF event days. The difference in CS between NPF events and nonevents follows from the distinctly different air masses arriving at Hyytiälä. For instance, it has been shown that air masses originating from the north and passing over Scandinavia have, on average, lower values of CS than the air masses passing over Russia and central Europe (Sogacheva et al., 2005; Nieminen et al., 2015).

On NPF event days, the median-approximated formation rate of $3 \mathrm{~nm}$ particles had its maximum value at about midday and was significantly higher than on nonevents days (Figs. 9b and 10). A clear negative relation could be seen between the median seasonal diurnal cycles of CS and $J_{3, C}$ on NPF event days (especially during spring daytime; Fig. 10). This kind of relation was not observed during nonevent days when these two quantities seemed to be independent of each other (Fig. 10). In summer, the median value of $J_{3, C}$ was roughly similar between NPF events and nonevents, whereas the median value of CS was almost 10 times higher during the nonevent days compared with event days. The high values of $J_{3, C}$ for the nonevent days in summer, despite the high CS values, seem to suggest that some other factor limits the actual NPF rate. One possibility is that freshly formed clusters are rapidly evaporated due to higher ambient temperatures (see Fig. 5b). This will be discussed in a more detail in the following section. Higher values of CS on nonevent days are
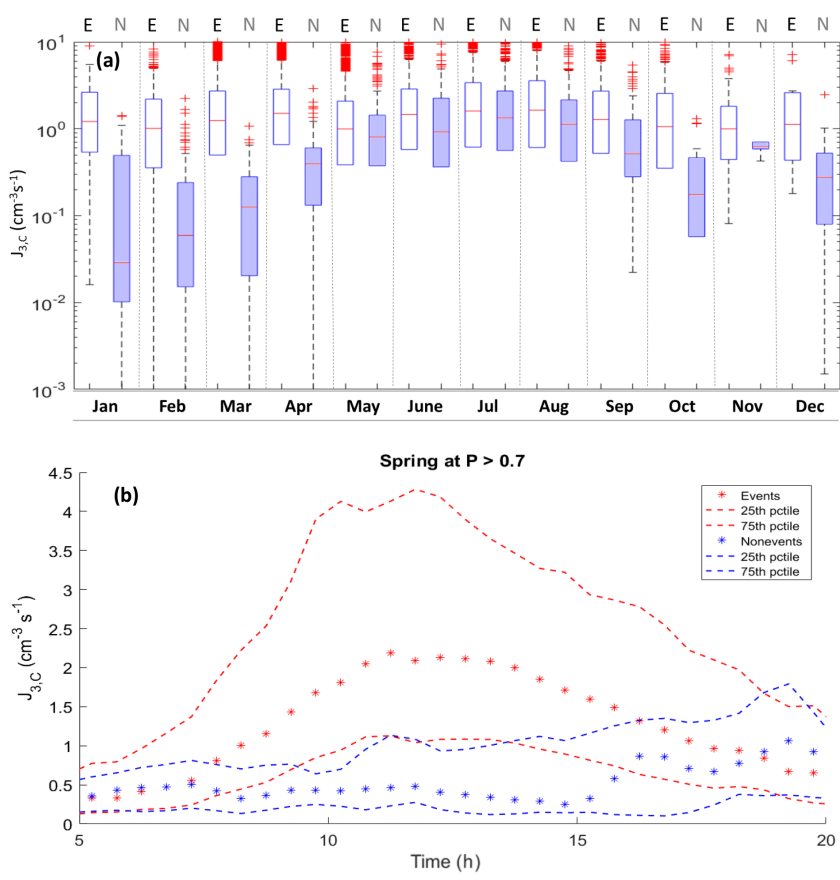

Figure 9. (a) Monthly variation of medians and percentiles of $J_{3, C}$ during the time window 09:00-12:00 of NPF events (E, white) and nonevents (N, shaded). See Fig. 1 for explanation of symbols. (b) The diurnal cycle of $J_{3, C}$ during spring. The nighttime is missing in this plot due to unavailable SA proxy which uses UVB to be calculated.

expected, bearing in mind that these particles act as surfaces for scavenging precursor gases and freshly formed particles (Hussein et al., 2008). The association of a high CS with the lower NPF probability has been observed in many studies conducted in Hyytiälä (Boy and Kulmala, 2002; Hyvönen et al., 2005; Baranizadeh et al., 2014), as well as in other rural and urban areas, including Egbert and Toronto in Canada (Jun et al., 2014), Preila in Lithuania (Mordas et al., 2016), Po Valley in Italy (Hamed et al., 2007) and Budapest and K-puszta in Hungary (Salma et al., 2016).

\subsubsection{Threshold separating the NPF events and nonevents}

Since quite a visible separation could be observed in the calculated values of $J_{3}, C$ between the springtime clear-sky NPF events and nonevents, and since $J_{3}, C$ had its maximum at around midday, the plot of CS versus temperature at midday (11:00-12:00) in spring provides an equation that effectively separates the NPF events from nonevents during this season (Fig. 11). This equation was determined using a linear discriminant analysis (LDA) similar to Hyvönen et al. (2005). The equation provides a line that separates NPF events from nonevents at $95 \%$ confidence towards nonevents. Based on their midday CS and temperature, the data point follows ei- 

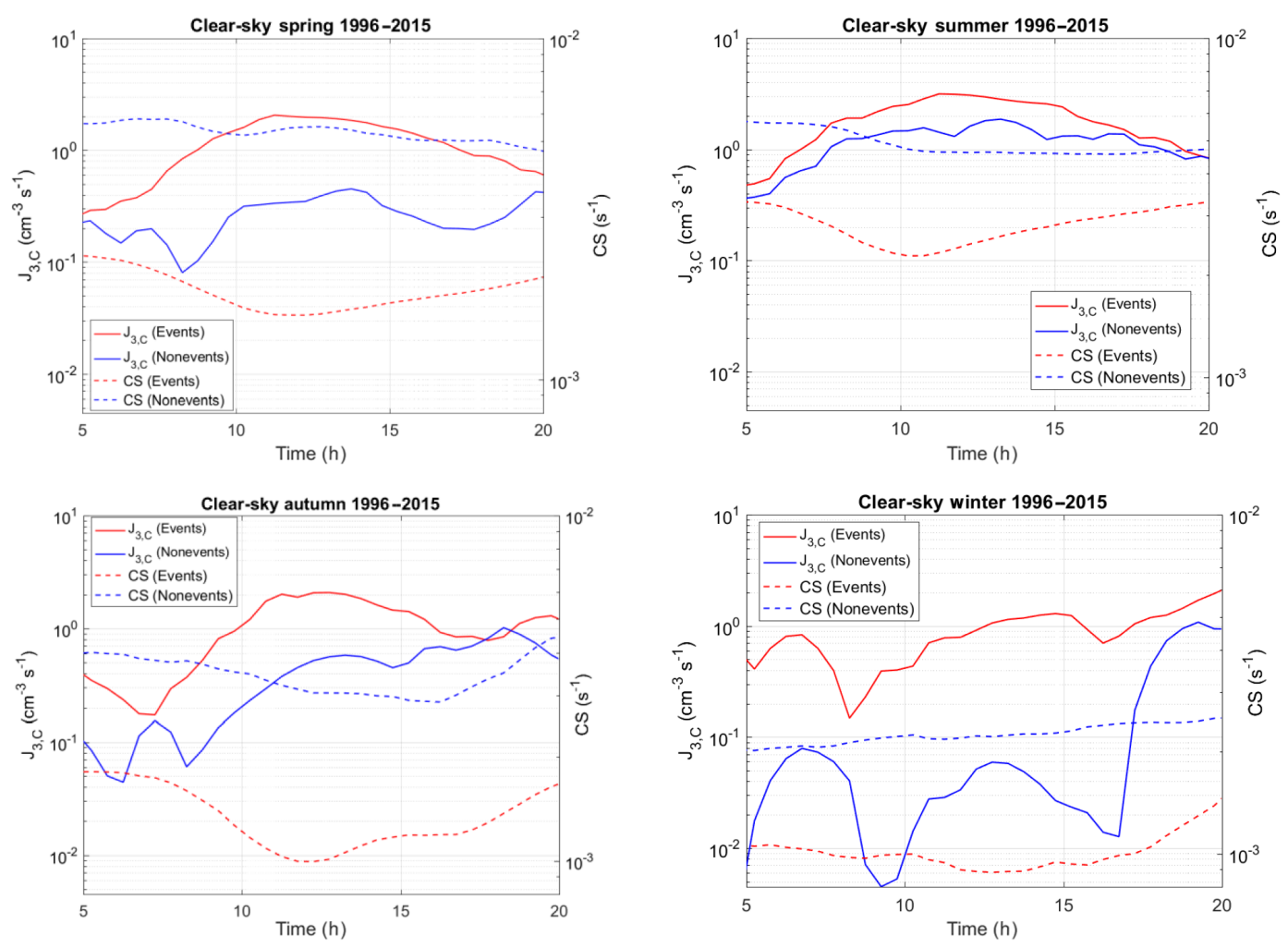

Figure 10. Diurnal cycle of median values of calculated formation rate of $3 \mathrm{~nm}$ particles $\left(J_{3, C}\right)$ and condensation sink $(\mathrm{CS})$ during different seasons for clear-sky events and nonevents.

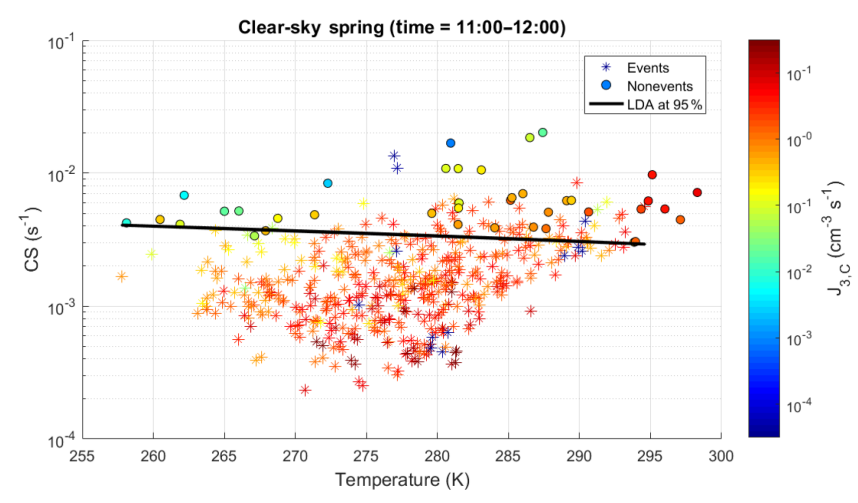

Figure 11. Relationship between temperature and CS during springtime (11:00-12:00) NPF clear-sky $(P>0.7)$ event days and nonevent days color-coded with $J_{3, C}$. Horizontal line is calculated from LDA at $95 \%$ confidence relative to nonevents and is demonstrated by Eq. (6).

ther classes. More specifically, the days with

$\mathrm{CS}\left(\mathrm{s}^{-1}\right)>-3.091 \times 10^{-5} \times T($ in Kelvin $)+0.0120$

lie above the threshold line. Almost no nonevent days fall below this line $(<5 \%)$. The points above the line were also characterized with higher trace gas concentrations and lower calculated formation rates of $3 \mathrm{~nm}$ particles than the rest of the points.

The separation between the clear-sky NPF events and nonevents in the CS versus $T$ plot was less evident in autumn and disappeared completely in the summer and winter (Fig. 12). Interestingly, a large number of NPF event days during these seasons still fell below the threshold line given by Eq. (6). Furthermore, we analyzed the effect of RH in separating the events from nonevents, similarly to the study done on RH by Hyvönen et al. (2005). We found that compared with CS versus temperature data, depicting CS versus RH (data not presented) did not work better for separating NPF events from nonevents during clear-sky conditions.

\subsubsection{Probability of NPF events and nonevents}

Since the biggest difference in the calculated $3 \mathrm{~nm}$ particle formation rates between the NPF events and nonevents was observed around noon (Fig. 9b), and since CS and temperature showed promising threshold values for predicting the occurrence of NPF nonevents during spring (up to $95 \%$ ) (Fig. 11), Fig. 13 presents the probability of having a NPF event in Hyytiälä at a specific CS and temperature within the time window 11:00-12:00. The probability was calculated by taking the fraction of events to the total events and nonevents in every cell which is $2.5 \mathrm{~K}$ on the $x$ axis and a 

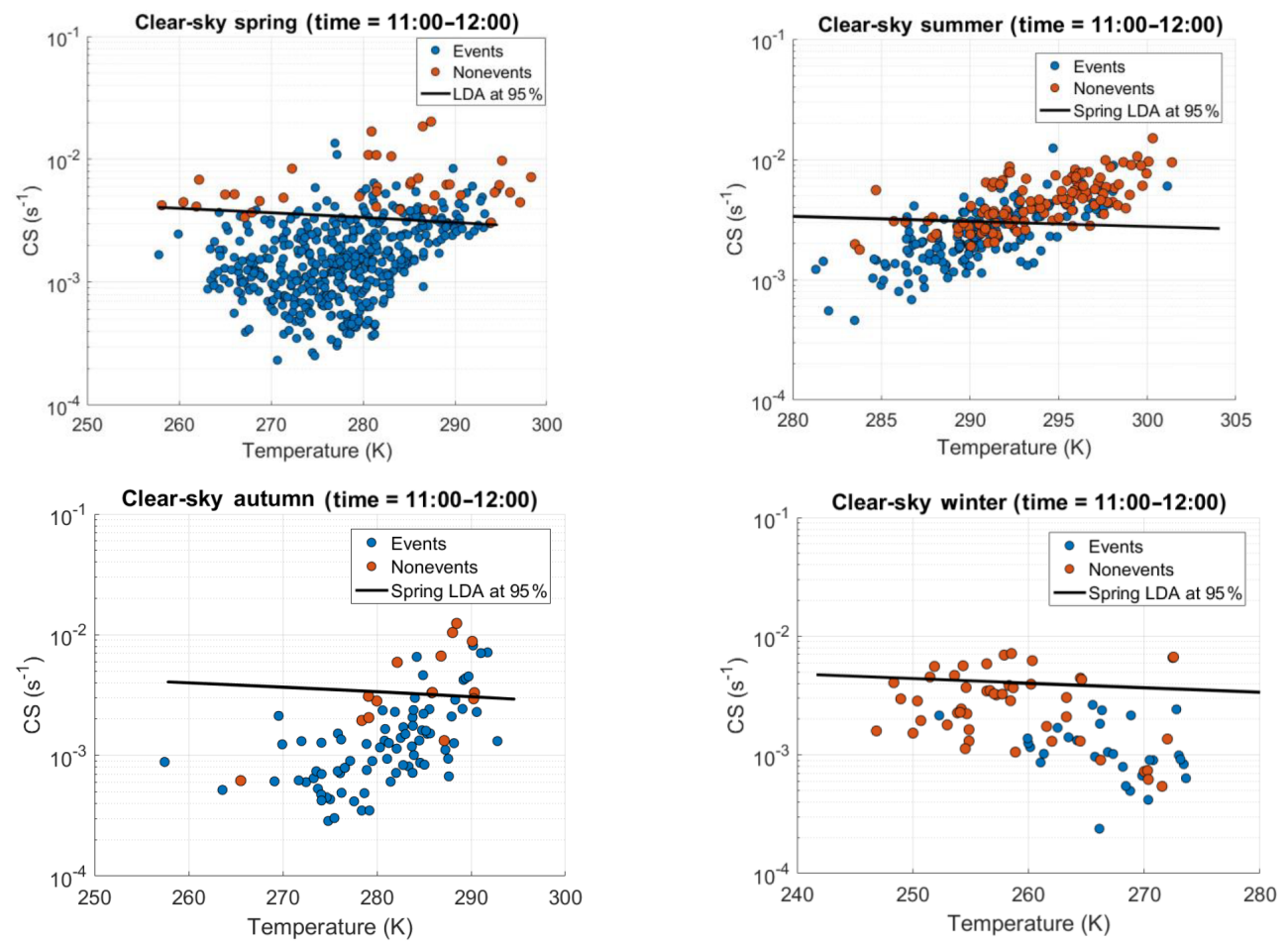

Figure 12. Relationship between CS and temperature (time window: 11:00-12:00) NPF clear-sky event days and nonevent days. Horizontal line is calculated from spring LDA at $95 \%$ confidence relative to nonevents and is demonstrated by Eq. (6).

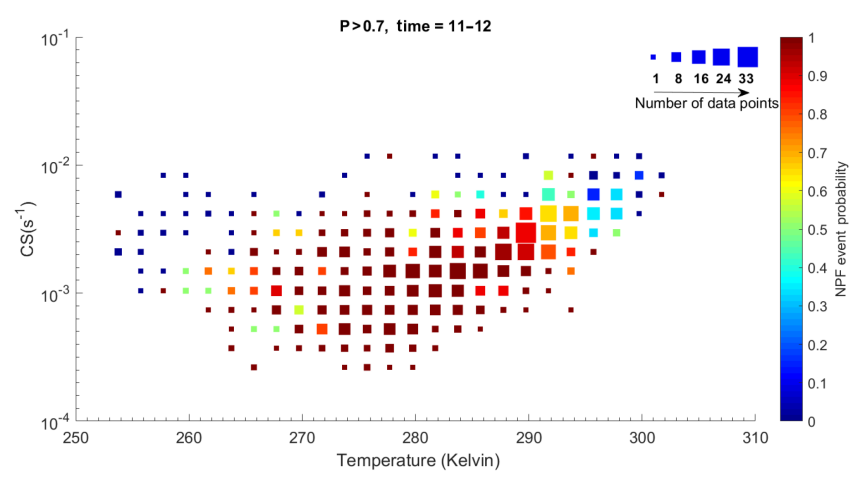

Figure 13. NPF probability distribution based on the CS and temperature conditions during clear-sky days (11:00-12:00). Marker size indicates number of days included in the probability calculation within every cell.

ratio of 1.14 on the $y$ axis between every two consecutive CS values. The highest probability of having a NPF event corresponded to conditions with moderate temperatures and low values of CS. At high values of CS, there was a zero probability for NPF regardless of the temperature. However, at moderate and low values of CS, the probability of having a NPF event decreases at lower temperatures. This could be explained by lower emissions of VOCs and thus lower OxOrg concentrations at lower temperatures. Similarly, the probability of NPF decreases at higher temperatures at constant values of CS. This latter feature might be attributed to conditions that are unfavorable for clustering due to high temperatures. Although previous studies have developed criteria for NPF probability which could work in diverse environments (Kuang et al., 2010), they did not explore the dependency of their parameter on atmospheric conditions.

\section{Conclusions}

In this study we combined 20 years of data collected at the SMEAR II station in order to characterize the conditions affecting the frequency of NPF events in that location. By focusing only on clear-sky conditions, we were able to get a new insight into differences between the NPF events and nonevents. In clear-sky conditions, the meteorological conditions, trace gas concentrations and other studied variables on NPF event days appeared to be similar to those presented in the previous studies which did not consider clear-sky classification. Furthermore, the monthly data refined the analysis so that the differences caused by different quantities became more visible compared the previous studies conducted for this site. Our work confirms the conclusions of Baranizadeh et al. (2014) with a complementary data set: NPF events and nonevents are typically associated with clear-sky and cloudy conditions, respectively.

Our results showed that using SA and OxOrg proxies to calculate the apparent formation rates of 1.5 and $3 \mathrm{~nm}$ par- 
ticles works well in differentiating the clear-sky NPF events from nonevents. Moreover, during clear-sky conditions the effect of CS on attenuating or even preventing NPF was quite visible: CS was, on average, two times higher on the nonevent days compared with the NPF event days. Similarly, many other meteorological variables affected NPF. By using CS and ambient temperature, we were able to find a threshold above which no clear-sky NPF events occurred. This threshold is described with an equation that is able to separate $97.4 \%$ of the NPF events from nonevents during springtime. In clear sky conditions, when there is plenty of radiation available, NPF events take place as long as the CS is low enough and temperature is moderate. Although a weaker separation was observed in the other seasons, considering only clear-sky conditions enabled us to form a map of the probability of having a NPF event within specific CS and temperature conditions. Using clear-sky conditions appears to bring us one step forward towards understanding NPF and predicting their occurrences in Hyytiälä. Our study serves as a basis of future detailed comparisons with observations to formulate even more robust conclusions.

Data availability. Data measured at the SMEAR II station are available on the following website: http://avaa.tdata.fi/web/smart/. The data are licensed under a Creative Commons 4.0 Attribution (CC BY) license. Backward air-mass trajectories are freely access from the transport model which is developed and provided by NOAA (National Oceanic and Atmospheric Administration) at (http://www.ready.noaa.gov/HYSPLIT.php). Input meteorological data required for 200 the model were collected from GDAS (Global Data Assimilation System) archives.

Competing interests. The authors declare that they have no conflict of interest.

Acknowledgements. This work was supported by the Academy of Finland Centre of Excellence program (grant no. 272041) and Nordic Top-level Research Initiative (TRI) CryosphereAtmosphere Interactions in a Changing Arctic Climate (CRAICC). Lubna Dada acknowledges the doctoral programme in Atmospheric Sciences (ATM-DP, University of Helsinki) for financial support. We also thank Ksenia Tabakova for providing air mass trajectory data.

Edited by: D. Spracklen

Reviewed by: two anonymous referees

\section{References}

Aalto, P., Hämeri, K., Becker, E., Weber, R., Salm, J., Mäkelä, J. M., Hoell, C., O'dowd, C. D., Hansson, H.-C., Väkevä, M., Koponen, I. K., Buzorius, G., and Kulmala, M.: Physical characterization of aerosol particles during nucleation events, Tellus B, 53, 344358 doi:10.1034/j.1600-0889.2001.530403.x, 2001.

Ahlm, L., Liu, S., Day, D. A., Russell, L. M., Weber, R., Gentner, D. R., Goldstein, A. H., DiGangi, J. P., Henry, S. B., Keutsch, F. N., VandenBoer, T. C., Markovic, M. Z., Murphy, J. G., Ren, X., and Scott, S.: Formation and growth of ultrafine particles from secondary sources in Bakersfield, California, J. Geophys. Res.Atmos., 117, D00V08, doi:10.1029/2011JD017144, 2012.

Apte, J. S., Marshall, J. D., Cohen, A. J., and Brauer, M.: Addressing global mortality from ambient PM2. 5, Environ. Sci. Technol., 49, 8057-8066, doi:10.1021/acs.est.5b01236, 2015.

Asmi, A., Wiedensohler, A., Laj, P., Fjaeraa, A.-M., Sellegri, K., Birmili, W., Weingartner, E., Baltensperger, U., Zdimal, V., and Zikova, N.: Number size distributions and seasonality of submicron particles in Europe 2008-2009, Atmos. Chem. Phys., 11, 5505-5538, doi:10.5194/acp-11-5505-2011, 2011.

Baranizadeh, E., Arola, A., Hamed, A., Nieminen, T., Mikkonen, S., Virtanen, A., Kulmala, M., Lehtinen, K., and Laaksonen, A.: The effect of cloudiness on new-particle formation: investigation of radiation levels, Boreal Environ. Res., 19, 343-354, 2014.

Bianchi, F., Tröstl, J., Junninen, H., Frege, C., Henne, S., Hoyle, C., Molteni, U., Herrmann, E., Adamov, A., Bukowiecki, N., Chen, X., Duplissy, J., Gysel, M., Hutterli, M., Kangasluoma, J., Kontkanen, J., Kürten, A., Manninen, H. E., Münch, S., Peräkylä, O., Petäjä, T., Rondo, L., Williamson, C., Weingartner, E., Curtius, J., Worsnop, D. R., Kulmala, M., Dommen, J., and Baltensperger, U.: New particle formation in the free troposphere: A question of chemistry and timing, Science, 352, 1109-1112, doi:10.1126/science.aad5456, 2016.

Boulon, J., Sellegri, K., Venzac, H., Picard, D., Weingartner, E., Wehrle, G., Collaud Coen, M., Bütikofer, R., Flückiger, E., and Baltensperger, U.: New particle formation and ultrafine charged aerosol climatology at a high altitude site in the Alps (Jungfraujoch, $3580 \mathrm{~m}$ asl, Switzerland), Atmos. Chem. Phys., 10, 93339349, doi:10.5194/acp-10-9333-2010, 2010.

Boy, M. and Kulmala, M.: Nucleation events in the continental boundary layer: Influence of physical and meteorological parameters, Atmos. Chem. Phys., 2, 1-16, doi:10.5194/acp-2-1-2002, 2002.

Buenrostro Mazon, S., Riipinen, I., Schultz, D., Valtanen, M., Maso, M. D., Sogacheva, L., Junninen, H., Nieminen, T., Kerminen, V.-M., and Kulmala, M.: Classifying previously undefined days from eleven years of aerosol-particle-size distribution data from the SMEAR II station, Hyytiälä, Finland, Atmos. Chem. Phys., 9, 667-676, doi:10.5194/acp-9-667-2009, 2009.

Buenrostro Mazon, S., Kontkanen, J., Manninen, H. E., Nieminen, T., Kerminen, V.-M., and Kulmala, M.: A long-term comparison of nighttime cluster events and daytime ion formation in a boreal forest, Boreal Environ. Res., 21, 242-261, 2016.

Bzdek, B. R., Lawler, M. J., Horan, A. J., Pennington, M. R., DePalma, J. W., Zhao, J., Smith, J. N., and Johnston, M. V.: Molecular constraints on particle growth during new particle formation, Geophys. Res. Lett., 41, 6045-6054, doi:10.1021/ac100856j, 2014.

Dada, L., Chellapermal, R., Buenrostro Mazon, S., Junninen, H., Kerminen, V. M., Paasonen, P., and Kulmala, M.: Method for identifying NPF event start and end times as well as NPF types (ion-initiated, particle initiated, transported) using characteris- 
tic nucleation-mode particles and air ions, Atmos. Chem. Phys. Dissc., in preparation, 2017.

Dal Maso, M., Kulmala, M., Riipinen, I., Wagner, R., Hussein, T., Aalto, P. P., and Lehtinen, K. E.: Formation and growth of fresh atmospheric aerosols: eight years of aerosol size distribution data from SMEAR II, Hyytiala, Finland, Boreal Environ. Res., 10, 323-336, 2005.

Donahue, N. M., Kroll, J., Pandis, S. N., and Robinson, A. L.: A two-dimensional volatility basis set - Part 2: Diagnostics of organic-aerosol evolution, Atmos. Chem. Phys., 12, 615-634, doi:10.5194/acp-12-615-2012, 2012.

Duplissy, J., Merikanto, J., Franchin, A., Tsagkogeorgas, G., Kangasluoma, J., Wimmer, D., Vuollekoski, H., Schobesberger, S., Lehtipalo, K., Flagan, R. C., Brus, D., Donahue, N. M., Vehkamäki, H., Almeida, J., Amorim, A., Barmet, P., Bianchi, F., Breitenlechner, M., Dunne, E. M., Guida, R., Henschel, H., Junninen, H., Kirkby, J., Kürten, A., Kupc, A., Määttänen, A., Makhmutov, V., Mathot, S., Nieminen, T., Onnela, A., Praplan, A. P., Riccobono, F., Rondo, L., Steiner, G., Tome, A., Walther, H., Baltensperger, U., Carslaw, K. S., Dommen, J., Hansel, A., Petäjä, T., Sipilä, M., Stratmann, F., Vrtala, A., Wagner, P. E., Worsnop, D. R.,, Curtius, and Kulmala, M.: Effect of ions on sulfuric acid-water binary particle formation: 2. Experimental data and comparison, J. Geophys. Res.-Atmos., 121, 1752-1775, doi:10.1002/2015JD023539, 2016.

Ehn, M., Thornton, J. A., Kleist, E., Sipilä, M., Junninen, H., Pullinen, I., Springer, M., Rubach, F., Tillmann, R., Lee, B., LopezHilfiker, F., Andres, S., Acir, I.-H., Rissanen, M., Jokinen, T., Schobesberger, S., Kangasluoma, J., Kontkanen, J., Nieminen, T., Kurtén, T., Nielsen, L. B., Jørgensen, S., Kjaergaard, H. G., Canagaratna, M., Maso, M. D., Berndt, T., Petäjä, T., Wahner, A., Kerminen, V.-M., Kulmala, M., Worsnop, D. R., Wildt, J., and Mentel, T. F.: A large source of low-volatility secondary organic aerosol, Nature, 506, 476-479, doi:10.1038/nature13032, 2014.

Hallquist, M., Wenger, J., Baltensperger, U., Rudich, Y., Simpson, D., Claeys, M., Dommen, J., Donahue, N., George, C., and Goldstein, A.: The formation, properties and impact of secondary organic aerosol: current and emerging issues, Atmos. Chem. Phys., 9, 5155-5236, doi:10.5194/acp-9-5155-2009, 2009.

Hamed, A., Joutsensaari, J., Mikkonen, S., Sogacheva, L., Maso, M. D., Kulmala, M., Cavalli, F., Fuzzi, S., Facchini, M., and Decesari, S.: Nucleation and growth of new particles in Po Valley, Italy, Atmos. Chem. Phys., 7, 355-376, doi:10.5194/acp-7-3552007, 2007.

Hamed, A., Korhonen, H., Sihto, S. L., Joutsensaari, J., Järvinen, H., Petäjä, T., Arnold, F., Nieminen, T., Kulmala, M., and Smith, J. N.: The role of relative humidity in continental new particle formation, J. Geophys. Res.-Atmos., 116, D3, 2011.

Hari, P. and Kulmala, M.: Station for measuring ecosystematmosphere relations, Boreal Environ. Res., 10, 315-322, 2005.

Hussein, T., Martikainen, J., Junninen, H., Sogacheva, L., Wagner, R., Dal Maso, M., Riipinen, I., Aalto, P. P., and Kulmala, M.: Observation of regional new particle formation in the urban atmosphere, Tellus B, 60, 509-521, doi:10.1111/j.16000889.2008.00365.x, 2008.

Hyvönen, S., Junninen, H., Laakso, L., Maso, M. D., Grönholm, T., Bonn, B., Keronen, P., Aalto, P., Hiltunen, V., Pohja, T., Launiainen, S., Hari, P., Mannila, H., and Kulmala, M.: A look at aerosol formation using data mining techniques, Atmos. Chem. Phys., 5, 3345-3356, doi:10.5194/acp-5-3345-2005, 2005.

Jun, Y.-S., Jeong, C.-H., Sabaliauskas, K., Leaitch, W. R., and Evans, G. J.: A year-long comparison of particle formation events at paired urban and rural locations, Atmos. Pollut. Res., 5, $447-$ 454, doi:10.5094/APR.2014.052, 2014.

Junninen, H., Hulkkonen, M., Riipinen, I., Nieminen, T., Hirsikko, A., Suni, T., Boy, M., LEE, S. H., Vana, M., Tammet, H., KERMINEN, V.-M., and KULMALA, M.: Observations on nocturnal growth of atmospheric clusters, Tellus B, 60, 365-371, doi:10.1111/j.1600-0889.2008.00356.x, 2008.

Kannosto, J., Virtanen, A., Lemmetty, M., Mäkelä, J. M., Keskinen, J., Junninen, H., Hussein, T., Aalto, P., and Kulmala, M.: Mode resolved density of atmospheric aerosol particles, Atmos. Chem. Phys., 8, 5327-5337, doi:10.5194/acp-8-5327-2008, 2008.

Kerminen, V.-M. and Kulmala, M.: Analytical formulae connecting the "real" and the "apparent" nucleation rate and the nuclei number concentration for atmospheric nucleation events, J. Aerosol Sci., 33, 609-622, doi:10.1016/S0021-8502(01)00194-X, 2002.

Kerminen, V.-M., Petäjä, T., Manninen, H., Paasonen, P., Nieminen, T., Sipilä, M., Junninen, H., Ehn, M., Gagné, S., Laakso, L., Riipinen, I., Vehkamäki, H., Kurten, T., Ortega, I. K., Maso, M. D., Brus, D., Hyvärinen, A., Lihavainen, H., Leppä, J., Lehtinen, K. E. J., Mirme, A., Mirme, S., Hõrrak, U., Berndt, T., Stratmann, F., Birmili, W., Wiedensohler, A., Metzger, A., Dommen, J., Baltensperger, U., Kiendler-Scharr, A., Mentel, T. F., Wildt, J., Winkler, P. M., Wagner, P. E., Petzold, A., Minikin, A., Plass-Dülmer, C., Pöschl, U., Laaksonen, A., and Kulmala, M.: Atmospheric nucleation: highlights of the EUCAARI project and future directions, Atmos. Chem. Phys., 10, 10829-10848, doi:10.5194/acp10-10829-2010, 2010.

Kerminen, V.-M., Paramonov, M., Anttila, T., Riipinen, I., Fountoukis, C., Korhonen, H., Asmi, E., Laakso, L., Lihavainen, H., Swietlicki, E., Svenningsson, B., Asmi, A., Pandis, S. N., Kulmala, M., and Petäjä, T.: Cloud condensation nuclei production associated with atmospheric nucleation: a synthesis based on existing literature and new results, Atmos. Chem. Phys., 12, 12037 12059, doi:10.5194/acp-12-12037-2012, 2012.

Kirkby, J., Curtius, J., Almeida, J., Dunne, E., Duplissy, J., Ehrhart, S., Franchin, A., Gagné, S., Ickes, L., Kürten, A., Kupc, A., Metzger, A., Riccobono, F., Rondo, L., Schobesberger, S., Georgios Tsagkogeorgas, Daniela Wimmer, Antonio Amorim, Bianchi, F., Martin Breitenlechner, André David, Josef Dommen, Downard, A., Ehn, M., Flagan, R. C., Haider, S., Hansel, A., Hauser, D., Jud, W., Junninen, H., Kreissl, F., Kvashin, A., Laaksonen, A., Lehtipalo, K., Lima, J., Lovejoy, E. R., Makhmutov, V., Mathot, S., Mikkilä, J., Minginette, P., Sandra Mogo, Nieminen, T., Onnela, A., Pereira, P., Petäjä, T., Schnitzhofer, R., Seinfeld, J. H., Sipilä, M., Stozhkov, Y., Stratmann, F., Tomé, A., Vanhanen, J., Viisanen, Y., Vrtala, A., Wagner, P. E., Walther, H., Weingartner, E., Wex, H., Winkler, P. M., Carslaw, K. S., Worsnop, D. R., Baltensperger, U., and Kulmala, M.: Role of sulphuric acid, ammonia and galactic cosmic rays in atmospheric aerosol nucleation, Nature, 476, 429-433, doi:10.1038/nature10343, 2011.

Kontkanen, J., Järvinen, E., Manninen, H. E., Lehtipalo, K., Kangasluoma, J., Decesari, S., Gobbi, G. P., Laaksonen, A., Petäjä, T., and Kulmala, M.: High concentrations of sub- $3 \mathrm{~nm}$ clusters and frequent new particle formation observed in the Po Val- 
ley, Italy, during the PEGASOS 2012 campaign, Atmos. Chem. Phys., 16, 1919-1935, doi:10.5194/acp-16-1919-2016, 2016 a.

Kontkanen, J., Paasonen, P., Aalto, J., Bäck, J., Rantala, P., Petäjä, T., and Kulmala, M.: Simple proxies for estimating the concentrations of monoterpenes and their oxidation products at a boreal forest site, Atmos. Chem. Phys., 16, 13291-13307, doi:10.5194/acp-16-13291-2016, 2016b.

Kontkanen, J., Lehtipalo, K., Ahonen, L., Kangasluoma, J., Manninen, H. E., Hakala, J., Rose, C., Sellegri, K., Xiao, S., Wang, L., Qi, X., Nie, W., Ding, A., Yu, H., Lee, S., Kerminen, V. M., Petäjä, T., and Kulmala, M.: Measurements of sub-3 nm particles using a particle size magnifier in different environments: from clean mountain top to polluted megacities, Atmos. Chem. Phys., 17, 2163-2187, doi:10.5194/acp-17-2163-2017, 2017.

Kuang, C., Riipinen, I., Sihto, S.-L., Kulmala, M., McCormick, A., and McMurry, P.: An improved criterion for new particle formation in diverse atmospheric environments, Atmos. Chem. Phys., 10, 8469-8480, doi:10.5194/acp-10-8469-2010, 2010.

Kulmala, M., Toivonen, A., Mäkelä, J. M., and Laaksonen, A.: Analysis of the growth of nucleation mode particles observed in Boreal forest, Tellus B, 50, 449-462, 10.3402/tellusb.v50i5.16229, 1998.

Kulmala, M., Vehkamäki, H., Petäjä, T., Dal Maso, M., Lauri, A., Kerminen, V.-M., Birmili, W., and McMurry, P. H.: Formation and growth rates of ultrafine atmospheric particles: a review of observations, J. Aerosol Sci., 35, 143-176, doi:10.1016/j.jaerosci.2003.10.003, 2004a.

Kulmala, M., Suni, T., Lehtinen, K. E. J., Dal Maso, M., Boy, M., Reissell, A., Rannik, Ü., Aalto, P., Keronen, P., Hakola, H., Bäck, J., Hoffmann, T., Vesala, T., and Hari, P.: A new feedback mechanism linking forests, aerosols, and climate, Atmos. Chem. Phys., 4, 557-562, doi:10.5194/acp-4-557-2004, 2004b.

Kulmala, M., Petäjä, T., Nieminen, T., Sipilä, M., Manninen, H. E., Lehtipalo, K., Dal Maso, M., Aalto, P. P., Junninen, H., and Paasonen, P.: Measurement of the nucleation of atmospheric aerosol particles, Nat. Protoc., 7, 1651-1667, doi:10.1038/nprot.2012.091, 2012.

Kulmala, M., Kontkanen, J., Junninen, H., Lehtipalo, K., Manninen, H. E., Nieminen, T., Petäjä, T., Sipilä, M., Schobesberger, S., Rantala, P., Franchin, A., Jokinen, T., Järvinen, E., Äijälä, M., Kangasluoma, J., Hakala, J., Aalto, P., Paasonen, P., Mikkilä, J., Vanhanen, J., Aalto, J., Hakola, H., Makkonen, U., Ruuskanen, T., Mauldin, R. r., Duplissy, J., Vehkamäki, H., Bäck, J., Kortelainen, A., Riipinen, I., Kurtén, T., Johnston, M., Smith, J., Ehn, M., Mentel, T., Lehtinen, K., Laaksonen, A., Kerminen, V., and Worsnop, D.: Direct observations of atmospheric aerosol nucleation, Science, 339, 943-946, doi:10.1126/science.1227385, 2013.

Kulmala, M., Luoma, K., Virkkula, A., Petäjä, T., Paasonen, P., Kerminen, V.-M., Nie, W., Qi, X., Shen, Y., and Chi, X.: On the mode-segregated aerosol particle number concentration load, Boreal Environ. Res., 21 319-331, 2016.

Kurtén, T., Torpo, L., Ding, C. G., Vehkamäki, H., Sundberg, M. R., Laasonen, K., and Kulmala, M.: A density functional study on water-sulfuric acid-ammonia clusters and implications for atmospheric cluster formation, J. Geophys. Res.-Atmos., 112, D04210, doi:10.1029/2006JD007391, 2007.

Liao, L., Kerminen, V.-M., Boy, M., Kulmala, M., and Dal Maso, M.: Temperature influence on the natural aerosol bud- get over boreal forests, Atmos. Chem. Phys., 14, 8295-8308, doi:10.5194/acp-14-8295-2014, 2014.

Merikanto, J., Spracklen, D., Mann, G., Pickering, S., and Carslaw, K.: Impact of nucleation on global CCN, Atmos. Chem. Phys., 9, 8601-8616, doi:10.5194/acp-9-8601-2009, 2009.

Merikanto, J., Duplissy, J., Määttänen, A., Henschel, H., Donahue, N. M., Brus, D., Schobesberger, S., Kulmala, M., and Vehkamäki, H.: Effect of ions on sulfuric acid-water binary particle formation: 1 . Theory for kinetic-and nucleation-type particle formation and atmospheric implications, J. Geophys. Res.Atmos., 121, 1736-1751, doi:10.1002/2015JD023538, 2016.

Metzger, A., Verheggen, B., Dommen, J., Duplissy, J., Prevot, A. S., Weingartner, E., Riipinen, I., Kulmala, M., Spracklen, D. V., and Carslaw, K. S.: Evidence for the role of organics in aerosol particle formation under atmospheric conditions, P. the Natl. Acad. Sci. USA, 107, 6646-6651, doi:10.1073/pnas.0911330107, 2010.

Mordas, G., Plauškaitè, K., Prokopciuk, N., Dudoitis, V., Bozzetti, C., and Ulevicius, V.: Observation of new particle formation on Curonian Spit located between continental Europe and Scandinavia, J. Aerosol Sci., 97, 38-55, doi:10.1016/j.jaerosci.2016.03.002, 2016.

Nieminen, T., Lehtinen, K., and Kulmala, M.: Sub-10 nm particle growth by vapor condensation-effects of vapor molecule size and particle thermal speed, Atmos. Chem. Phys., 10, 9773-9779, doi:10.5194/acp-10-9773-2010, 2010, 2010.

Nieminen, T., Asmi, A., Dal Maso, M., Aalto, P. P., Keronen, P., Petäjä, T., Kulmala, M., and Kerminen, V.-M.: Trends in atmospheric new-particle formation: 16 years of observations in a boreal-forest environment, Boreal Environ. Res., 19, 191-214, 2014.

Nieminen, T., Yli-Juuti, T., Manninen, H., Petäjä, T., Kerminen, V.-M., and Kulmala, M.: Technical note: New particle formation event forecasts during PEGASOS-Zeppelin Northern mission 2013 in Hyytiälä, Finland, Atmos. Chem. Phys., 15, 1238512396, doi:10.5194/acp-15-12385-2015, 2015.

Paasonen, P., Nieminen, T., Asmi, E., Manninen, H., Petäjä, T., Plass-Dülmer, C., Flentje, H., Birmili, W., Wiedensohler, A., Horrak, U., Metzger, A., Hamed, A., Laaksonen, A., Facchini, M. C., Kerminen, V.-M., and Kulmala, M.: On the roles of sulphuric acid and low-volatility organic vapours in the initial steps of atmospheric new particle formation, Atmos. Chem. Phys., 10, 11223-11242, doi:10.5194/acp-10-11223-2010, 2010.

Paasonen, P., Olenius, T., Kupiainen, O., Kurtén, T., Petäjä, T., Birmili, W., Hamed, A., Hu, M., Huey, L., Plass-Duelmer, C., Smith, J. N., Wiedensohler, A., Loukonen, V., McGrath, M. J., Ortega, I. K., Laaksonen, A., Vehkamäki, H., Kerminen, V.-M., and Kulmala, M.: On the formation of sulphuric acid-amine clusters in varying atmospheric conditions and its influence on atmospheric new particle formation, Atmos. Chem. Phys., 12, 9113-9133, doi:10.5194/acp-12-9113-2012, 2012.

Paasonen, P., Asmi, A., Petäjä, T., Kajos, M. K., Äijälä, M., Junninen, H., Holst, T., Abbatt, J. P., Arneth, A., Birmili, W., Gon, H. D. v. d., Hamed, A., Hoffer, A., Laakso, L., Laaksonen, A., Leaitch, W. R., Plass-Dülmer, C., Pryor, S. C., Räisänen, P., Swietlicki, E., Wiedensohler, A., Worsnop, D. R., Kerminen, V.-M., and Kulmala, M.: Warming-induced increase in aerosol number concentration likely to moderate climate change, Nat. Geosci., 6, 438-442, doi:10.1038/ngeo1800, 2013. 
Perez, R., Ineichen, P., Seals, R., and Zelenka, A.: Making full use of the clearness index for parameterizing hourly insolation conditions, Solar Energ., 45, 111-114, doi:10.1016/0038092X(90)90036-C, 1990.

Petäjä, T., Mauldin Iii, R., Kosciuch, E., McGrath, J., Nieminen, T., Paasonen, P., Boy, M., Adamov, A., Kotiaho, T., and Kulmala, M.: Sulfuric acid and $\mathrm{OH}$ concentrations in a boreal forest site, Atmos. Chem. Phys., 9, 7435-7448, doi:10.5194/acp-97435-2009, 2009.

Petäjä, T., Sipilä, M., Paasonen, P., Nieminen, T., Kurtén, T., Ortega, I. K., Stratmann, F., Vehkamäki, H., Berndt, T., and Kulmala, M.: Experimental observation of strongly bound dimers of sulfuric acid: Application to nucleation in the atmosphere, Physical review letters, 106, 228302, doi:10.1103/PhysRevLett.106.228302, 2011.

Pöschl, U.: Atmospheric aerosols: composition, transformation, climate and health effects, Angewandte Chemie International Edition, 44, 7520-7540, doi:10.1002/anie.200501122, 2005.

Riccobono, F., Schobesberger, S., Scott, C. E., Dommen, J., Ortega, I. K., Rondo, L., Almeida, J., Amorim, A., Bianchi, F., Breitenlechner, M., David, A., Downard, A., Dunne, E. M., Duplissy, J., Ehrhart, S., Flagan, R. C., Franchin, A., Hansel, A., Junninen, H., Kajos, M., Keskinen, H., Kupc, A., Kürten, A., Kvashin, A. N., Laaksonen, A., Lehtipalo, K., Makhmutov, V., Mathot, S., Nieminen, T., Onnela, A., Petäjä, T., Praplan, A. P., Santos, F. D., Schallhart, S., Seinfeld, J. H., Sipilä, M., Spracklen, D. V., Stozhkov, Y., Stratmann, F., Tomé, A., Tsagkogeorgas, G., Vaattovaara, P., Viisanen, Y., Vrtala, A., Wagner, P. E., Weingartner, E., Wex, H., Wimmer, D., Carslaw, K. S., Curtius, J., Donahue, N. M., Kirkby, J., Kulmala, M., Worsnop, D. R., and Baltensperger, U.: Oxidation products of biogenic emissions contribute to nucleation of atmospheric particles, Science, 344, $717-$ 721, doi:10.1126/science.1243527, 2014.

Salma, I., Németh, Z., Kerminen, V.-M., Aalto, P., Nieminen, T., Weidinger, T., Molnár, Á., Imre, K., and Kulmala, M.: Regional effect on urban atmospheric nucleation, Atmos. Chem. Phys., 16, 8715-8728, doi:10.5194/acp-16-8715-2016, 2016.

Sánchez, G., Serrano, A., and Cancillo, M.: Effect of cloudiness on solar global, solar diffuse and terrestrial downward radiation at Badajoz (Southwestern Spain), Optica pura y aplicada, 45, 3338, 2012.
Seinfeld, J. H. and Pandis, S. N.: Atmospheric chemistry and physics: from air pollution to climate change, John Wiley \& Sons, 2012.

Smith, J. N., Moore, K. F., Eisele, F. L., Voisin, D., Ghimire, A. K., Sakurai, H., and McMurry, P. H.: Chemical composition of atmospheric nanoparticles during nucleation events in Atlanta, J. Geophys. Res.-Atmos., 110, D22S03, doi:10.1029/2005JD005912, 2005.

Sogacheva, L., Dal Maso, M., Kerminen, V.-M., and Kulmala, M.: Probability of nucleation events and aerosol particle concentration in different air mass types arriving at Hyytiälä, southern Finland, based on back trajectories analysis, Boreal Environ. Res., 10, 493-510, 2005.

Sogacheva, L., Saukkonen, L., Nilsson, E., Dal Maso, M., Schultz, D. M., De Leeuw, G., and Kulmala, M.: New aerosol particle formation in different synoptic situations at Hyytiälä, southern Finland, Tellus B, 60, 485-494, doi:10.1111/j.16000889.2008.00364.x, 2008.

Vakkari, V., Tiitta, P., Jaars, K., Croteau, P., Beukes, J. P., Josipovic, M., Kerminen, V. M., Kulmala, M., Venter, A. D., and Zyl, P. G.: Reevaluating the contribution of sulfuric acid and the origin of organic compounds in atmospheric nanoparticle growth, Geophys. Res. Lett., 42, 10486-10493, doi:10.1002/2015GL066459, 2015.

Vehkamäki, H., Kulmala, M., Napari, I., Lehtinen, K. E., Timmreck, C., Noppel, M., and Laaksonen, A.: An improved parameterization for sulfuric acid-water nucleation rates for tropospheric and stratospheric conditions, J. Geophys. Res.-Atmos., 107, 4622, doi:10.1029/2002JD002184, 2002.

Yu, F., Luo, G., Bates, T. S., Anderson, B., Clarke, A., Kapustin, V., Yantosca, R. M., Wang, Y., and Wu, S.: Spatial distributions of particle number concentrations in the global troposphere: Simulations, observations, and implications for nucleation mechanisms, J. Geophys. Res.-Atmos., 115, D17205, doi:10.1029/2009JD013473, 2010.

Zhang, R., Khalizov, A., Wang, L., Hu, M., and Xu, W.: Nucleation and growth of nanoparticles in the atmosphere, Chem. Rev., 112, 1957-2011, doi:10.1021/cr2001756, 2011. 